\title{
Revolutionary of radio
}

\section{W. Bernard Carlson hails a life of driven communications pioneer Guglielmo Marconi.}

A s inventor of the wireless telegraph, Guglielmo Marconi was a central figure in the development of twentiethcentury communications. Yet how should we view him? As Nobel laureate? Entrepreneur? Fascist? In his grand, wide-ranging biography Marconi, Marc Raboy reveals a complex individual who played all these parts. By examining them, Raboy seeks to show how radio came to be intertwined with big business, imperialism and global politics in ways that still define electronic communications.

Marconi was born to privilege in 1874: his father was an Italian aristocrat, his mother a member of the Jameson Irish-whiskey dynasty. Educated in England and Italy, Marconi decided at age 20 to study the electromagnetic waves predicted by James Clerk Maxwell in the 1860s and verified experimentally by German physicist Heinrich Hertz some 20 years later. Marconi wanted to use these waves to develop a wireless telegraph system. He sent messages across his father's estate by using a Hertzian spark-gap transmitter to generate radio waves, which were detected by a version of the 'coherer' invented by French physicist Éduoard Branly (iron filings in a glass tube lined up in response to the waves). Marconi's breakthrough was in connecting these two devices to elevated aerials.

To commercialize this invention, Marconi's mother took him to England in 1896 to confer with her family, as well as William Preece, chief engineer of the British Post Office. A cousin, Henry Jameson Davis, helped Marconi to secure patents, launch the Wireless Telegraph and Signal Company (later Marconi’s Wireless Telegraph Company) and seek capital. Marconi concentrated on increasing transmission distances; he had sent messages across the English Channel by early 1899 .

Despite media acclaim and rising share prices, Marconi's company wasn't turning a profit. While his board dithered, Marconi decided to take a dramatic step to capture the ship-to-shore communication market. The Serbian-American inventor Nikola Tesla had promised to send a wireless message across the Atlantic (W. P. McCray Nature 497, 562563; 2013). Perhaps taking a cue from that, Marconi began working with British electrical engineer John Ambrose Fleming (who later invented the vacuum tube), to build a powerful transmitting station in Cornwall, UK. In December 1901, Marconi beat Tesla by

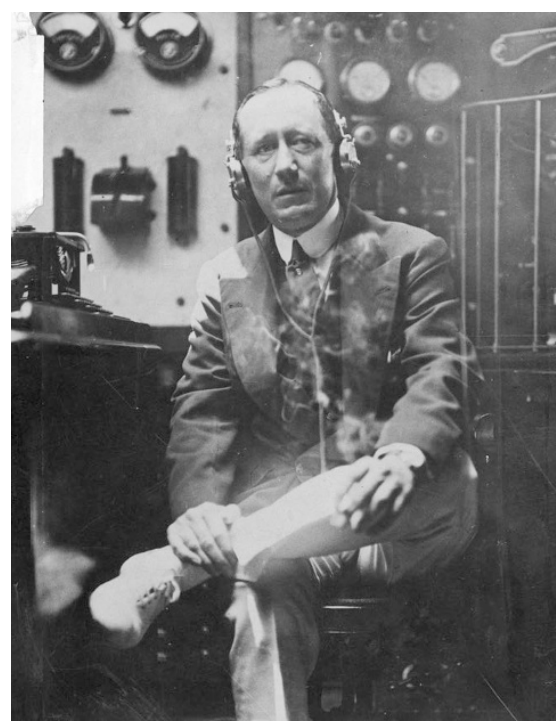

Guglielmo Marconi on his yacht, Elettra, in 1922.

receiving in St John's, Newfoundland, a message sent from the Cornwall station.

Marconi's enterprise flourished, selling wireless apparatus to shipping companies and navies around the world. Anxious to prevent the British from monopolizing the new technology, German emperor Wilhelm II supported the creation of the company Telefunken to advance German radio inventors, and convened the first international telecommunications conference in Berlin in 1903. The Germans wanted all ships to be able to communicate with all shore stations, whereas the British insisted that the Marconi system should be accessible solely to Marconi customers. Drawing on his background as a scholar of ethics, media and communications, Raboy effectively traces how Marconi and his managers manoeuvred through this emergent world of communications policy.

Marconi became a scientific celebrity. He won a share in the 1909 Nobel Prize in Physics. He served as Italy's head of radio operations during the First World War, and in 1919 represented the country at the Paris Peace Conference called by the Allied victors. Marconi found the negotiations frustrating, concluding that handling nature was easier than handling human nature. With his fellow Italian delegates, Marconi was also incensed that the Allies refused to cede to Italy the city of Fiume (now Rijeka, Croatia) and the Dalmatian coast. He came away from the conference sympathetic to Italian nationalism.

That led him to support the Fascists, and in 1927 Benito Mussolini appointed him to head Italy's national research council; later, he became president of the new academy of science. Using records recently discovered in the government archives in Rome, Raboy provides a detailed account of Marconi's involvement in Fascism, including his tacit approval of excluding Jewish scientists from the academy. In the 1930s, Marconi conducted radio experiments from his yacht, Elettra, and built a powerful radio station for the Vatican. He died in 1937, and various companies continued to use his name until Marconi plc was purchased by Ericsson in 2006.

Raboy superbly traces every twist and turn of Marconi's life, showing us his influences, business strategies and shrewd management of his own public persona. Raboy skilfully locates his activities in the context of communications policy, the arms race between Britain and Germany, and popular culture. But has he made the case that Marconi networked the world, as his book's subtitle claims? He asserts that Marconi envisioned global communications from the outset, but provides little early evidence to support this. I suspect that, like other inventors, Marconi was mostly worried about getting his apparatus to work and finding customers. The big global vision came in the 1920s, with his company's success in transmitting worldwide.

Raboy is also curiously indifferent to details of the technology or Marconi's rivals. One of Marconi's early breakthroughs was learning how to tune circuits using 'jigger' coils. Raboy offers no explanation of how this invention worked or how tuning allowed Marconi to send private messages from one point to another. Would we settle for a biography of Pablo Picasso that didn't explain Cubism?

Similarly, Marconi's rivals - including Oliver Lodge in Britain, Tesla in the United States, and Adolf Slaby and Karl Ferdinand Braun in Germany - are quickly dismissed by Raboy. Yet Marconi was well aware that he was racing against these competitors: that is why he vigorously challenged them through patent litigation, advertising and newspaper interviews. Our networked world didn't spring from the mind of one genius, but from a social network of talented rivals, all contributing to the electronic communications that today both enrich and complicate our lives.

W. Bernard Carlson is the Joseph L. Vaughan Professor of Humanities at the University of Virginia in Charlottesville and author of Tesla.

e-mail:wc4p@eservices.virginia.edu 